\title{
Article
}

\section{A Game for Christmas? The Argylls, Saxons and Football on the Western Front, December 1914}

\author{
Adams, lain Christopher
}

Available at http://clok.uclan.ac.uk/6916/

Adams, lain Christopher (2015) A Game for Christmas? The Argylls, Saxons and Football on the Western Front, December 1914. The International Journal of the History of Sport, 32 (11-112). pp. 1395-1415. ISSN 0952-3367

It is advisable to refer to the publisher's version if you intend to cite from the work.

For more information about UCLan's research in this area go to http://www.uclan.ac.uk/researchgroups/ and search for < name of research Group>.

For information about Research generally at UCLan please go to http://www.uclan.ac.uk/research/

All outputs in CLoK are protected by Intellectual Property Rights law, including Copyright law. Copyright, IPR and Moral Rights for the works on this site are retained by the individual authors and/or other copyright owners. Terms and conditions for use of this material are defined in the policies page.

\section{CLoK}

Central Lancashire online Knowledge www.clok.uclan.ac.uk

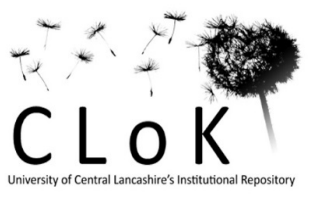




\title{
A Game for Christmas? The Argylls, Saxons and Football on the Western Front, December 1914
}

Iain Adams, International Football Institute, University of Central Lancashire.

\begin{abstract}
Historians know that any mention of football and World War I will involve discussions of the Christmas truces of 1914 and the mythical football match between British and German troops. Many British soldiers denied that any truce had occurred let alone a football match. However there is indisputable evidence of truces, but triangulating proof of football has been elusive. In this paper a case study of the British 2/Argylls and the German 133/Saxons is developed. The underlying reasons behind the truce are discussed and why some combatants, in the short break from trying to kill each other, probably played football, even though certainly not as the formal match of popular imagination. It is argued that the truce was a result of unique circumstances and was not an overwhelmingly inspirational moment for the majority of troops involved; they all returned to the fighting. Most participants on both sides of the truce probably regarded it as an unexpected holiday and some availed themselves of the opportunity to play their favourite game. The paper concludes by examining recent commemorative events of Christmas 1914 and how they may have contributed to the myth of 'The Football Match'.
\end{abstract}

Keywords: Christmas Truce; football; World War I; Argyll and Sutherland Highlanders; 133 Royal Saxon Regiment. 


\section{Introduction}

The centenary of the beginning of the First World War witnessed a significant upsurge in interest in the war and especially in the events of Christmas 1914. There has been a concomitant increase in attention to the relationship between sport and war and Robert Hands observed that the most famous example of this symbiosis was the 'unlikely and impromptu game of football between the Allies and Germans on Christmas Day 1914.' He opined this has moved 'towards the clichéd in histories of the First World War' and Wray Vamplew reflected that this event was a micro-level 'myth'; a story containing elements of truth. ${ }^{1}$ Years before the centenary Brown and Seaton recognised that:

To many people it has come to be accepted that the central feature of the Christmas truce of 1914 was a game, or possibly games, of football in which British and Germans took part. Indeed to some the whole event is not so much 'the truce' as 'the football match'. ${ }^{2}$

Brown and Seaton's book was first published in 1984, in the decade identified by Emma Hanna as being when the 'mythical idea of an all-encompassing Christmas Truce' in Britain was established. ${ }^{3}$ Recently British Council research revealed that 'the Christmas Truce' is one of the most recognised moments of the Great War with more than two-thirds of adults aware of 'the football match' that took place. ${ }^{4}$ When plans for the official commemoration of the Christmas truces were announced journalists wrote of 'Britain's plans for commemorating the centenary of the First World War include recreating the football match played against German troops'.5

Perhaps the most famous account of Christmas truce football was by Oberstleutnant Johannes Niemann of the German 133 Royal Saxon regiment (133/Saxons) in the 1968 BBC radio documentary Christmas Day Passed Quietly: 
Our Regiment and the Scottish Seaforth Highlanders were face to face ... suddenly my orderly threw himself into my dugout to say that both the German and Scottish soldiers had come out of their trenches and were fraternizing along the front. I grabbed my binoculars and looking cautiously over the parapet saw the incredible sight of our soldiers exchanging cigarettes, schnapps and chocolate with the enemy. Later a Scottish soldier appeared with a football which seemed to come from nowhere and a few minutes later a real football match got underway. The Scots marked their goal mouth with their strange caps and we did the same with ours. It was far from easy to play on the frozen ground, but we continued, keeping rigorously to the rules, despite the fact that it only lasted an hour and that we had no referee. A great many of the passes went wide, but all the amateur footballers, although they must have been very tired, played with huge enthusiasm. Us Germans really roared when a gust of wind revealed that the Scots wore no drawers under their kilts - and hooted and whistled every time they caught an impudent glimpse of one posterior belonging to one of 'yesterday's enemies'... The game finished with a score of three goals to two in favour of Fritz against Tommy. ${ }^{6}$

The BBC archives reveal that Niemann was unsure of which regiment was opposite him but it has since been established it was the 2 Battalion of the Argyll and Sutherland Highlanders (2/Argylls). ${ }^{7}$ The excellent overall histories of the Christmas truces, Brown and Seaton's Christmas Truce and Weintraub's Silent Night, fail to triangulate and integrate the evidence they present regarding the participation of the 2/Argylls and the 133/Saxons in a truce. ${ }^{8}$ This 
case study seeks to establish the actualité of football and these two enemy regiments' experiences at Christmas 1914.

\section{Setting the Scene}

By November 1, 1914, Erich von Falkenhayn, the German Chief of Staff, knew that the Schlieffen Plan had failed and concluded that continuing the manoeuvring war could result in defeat. Therefore, he ordered 'hold on to what you have and never surrender a square foot of that which you have won. ${ }^{99}$ This resulted in the adversaries constructing two sets of parallel defensive lines from the Belgian coast to the Swiss border, about 450 miles, with No Man's Land typically between 100 to 400 yards in width. ${ }^{10}$ The paradigmatic trench war had begun.

The soldiers of both sides became subjected to the continuous stress of sniping and shelling forcing troop rotation systems to be developed. At this stage the British held a sector from just south of Ypres to Givenchy and they established a typical trench rhythm of three to seven days in the firing line, then the same in the support trenches, which were usually about 100 to 150 yards behind the front line, and then a similar period in the reserve trenches about a quarter of a mile further back. These three lines of trenches were connected by communication trenches. After these three stints in the troglodyte world, the troops could look forward to approximately a week out of the lines in billets. ${ }^{11}$

\section{Live and let live}

The men on both sides of No Man's Land in the winter of 1914/1915 knew that the vicious fighting of the manoeuvring war had led to manpower and ammunition shortages and no meaningful strategic offensive was possible by either side before spring. The British Expeditionary Force (BEF) had arrived in France in August 1914 with about 70,000 men and had suffered about 90,000 men killed, wounded or 
missing in the period between August and November $1914 .{ }^{12}$ Typically battalions had lost $80 \%$ of their officers and $70 \%$ of the men who had originally landed. ${ }^{13}$ The BEF casualties were replaced by reservists, regular battalions recalled from Empire duties, territorial battalions and an Indian Army Corps. ${ }^{14}$ The French and Germans had each suffered about 300,000 men killed in action and approximately 700,000 missing or wounded.

The start of trench warfare was soon followed by the arrival of winter weather and in December more rain fell than in any December since 1876, over six inches. This made large scale movement impossible and added to the unlikelihood of a major attack by either side. ${ }^{15}$ In low lying areas, such as the River Lys flood plain, where the 2/Argylls and the 133/Saxons faced each other, the trenches became barely tenable; water pumps, hose pipes, shovels and pick axes became as important as rifles and breastworks began to replace trenches as defensive structures in the worst areas.

The troops on both sides were exhausted, frozen, disillusioned, and questioned their immediate purpose as many saw no advantage in killing one or two of the enemy and risking reprisals. Infantrymen passed messages to their artillery not to fire on the enemy at meal times as they did not want their own meals interrupted by retaliation. Lieutenant Hutchison of the 2/Argylls noted:

As we sat in the stillness we could hear with great distinctness the sound of transport on the Radinghem road bringing up the German rations, in the same way as they must have heard the wheels of our wagons rumbling through the streets of Houplines and down the dogleg road. But there seems to have been some unwritten law of "live and let live," for the ration parties of either side were never "strafed", ${ }^{16}$ 
On December 2, 1914, Rudolph Binding, commander of a Jungdeutschland dragoon squadron, wrote:

For truly ... there is no longer any sense in this business. The fraternization that has been going on between our trenches and those of the enemy, when friend and foe alike go to fetch straw from the same rick to protect them from the cold and rain and to have some sort of bedding to lie on - and never a shot is fired. ${ }^{17}$

The stalemate and close proximity of the combatants allowed them to become familiar with each other's activities and they realized that their opponents' miseries, such as lice, rats, mud, the cold and senior officers, mirrored their own; they shared a common humanity. Also they had mutual cultural and religious traditions. In the main, the soldiers on both sides were Christians resulting in many probably feeling it was wrong to be at war at Christmas; especially as they seemed to be only fighting, at that moment, for survival and to protect their regimental families. Belgian and French cabbage patches were not La mè bre patrie to the British or Germans. In Germany particularly, Christmas was a deeply emotive and family occasion, even for German Jewish soldiers this was 'the highest and most beautiful of all holidays'. ${ }^{18}$

These tacit agreements to reduce the violence became endemic in the trenches particularly in 'quiet sectors' or in the more tranquil times between major offensives; the Christmas truces were neither the first nor last but were the most vivid. ${ }^{19}$ Instances of informal live and let live accommodations between enemies have been recorded in nearly all wars dating back to the mythical Trojan War over 3,000 years ago and probably in most instances, as in World War I, the opposing troops who reduced hostilities took care to conceal the fact from higher military authority. 
Fraternisation was being reported in the press and led to hopes for a formal armistice over Christmas (Figure 1). Although this image was published in The Illustrated London News (ILN) on December 26, 1914 it must have been 'worked up' well before Christmas. Writing on December 18 ILN columnist Charles Lowe

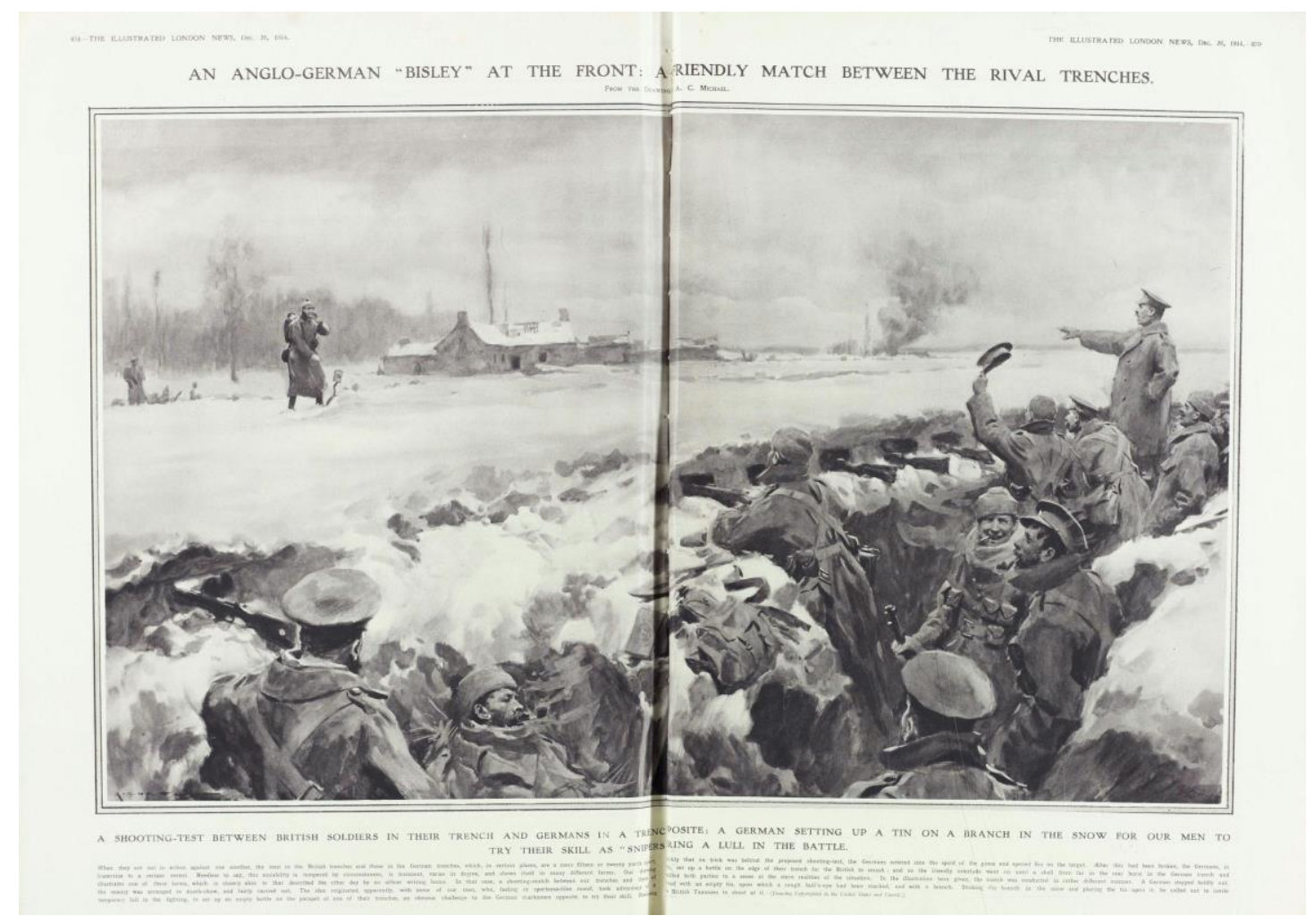

Figure 1 An Anglo-German Bisley by A.C. Michael. ILN 26 December 1915

forecast "for Christmastide there will probably be something like a "truce of God" - if not by mutual agreement, at least by common assent' ${ }^{20}$

The possibility of mutually agreed local truces was recognized by High Command on both sides and directives were issued forbidding fraternization. British General Headquarters (GHQ) ordered trench raids and larger tactical attacks between December 14 and 19 to keep the troops aggressive. These left numerous dead in No Man's Land for no significant gains and led to some of the Christmas truces as the 
soldiers remaining wished to bury their comrades out of respect for the dead, to escape the sight and smell, and to help prevent disease.

\section{Christmas in the trenches at Houplines, 1914}

\section{Christmas Eve}

On December 20, after nine days of rest, the 2/Argylls left their billets in the Armentières lunatic asylum at 16:15 and marched to the lines east of Houplines where they completed the relief of the 1/Middlesex by 19:35. Their area of responsibility stretched from Hobbs Farm in the north to Pont Ballot in the south, a distance of approximately one mile (Figure 2$).^{21}$

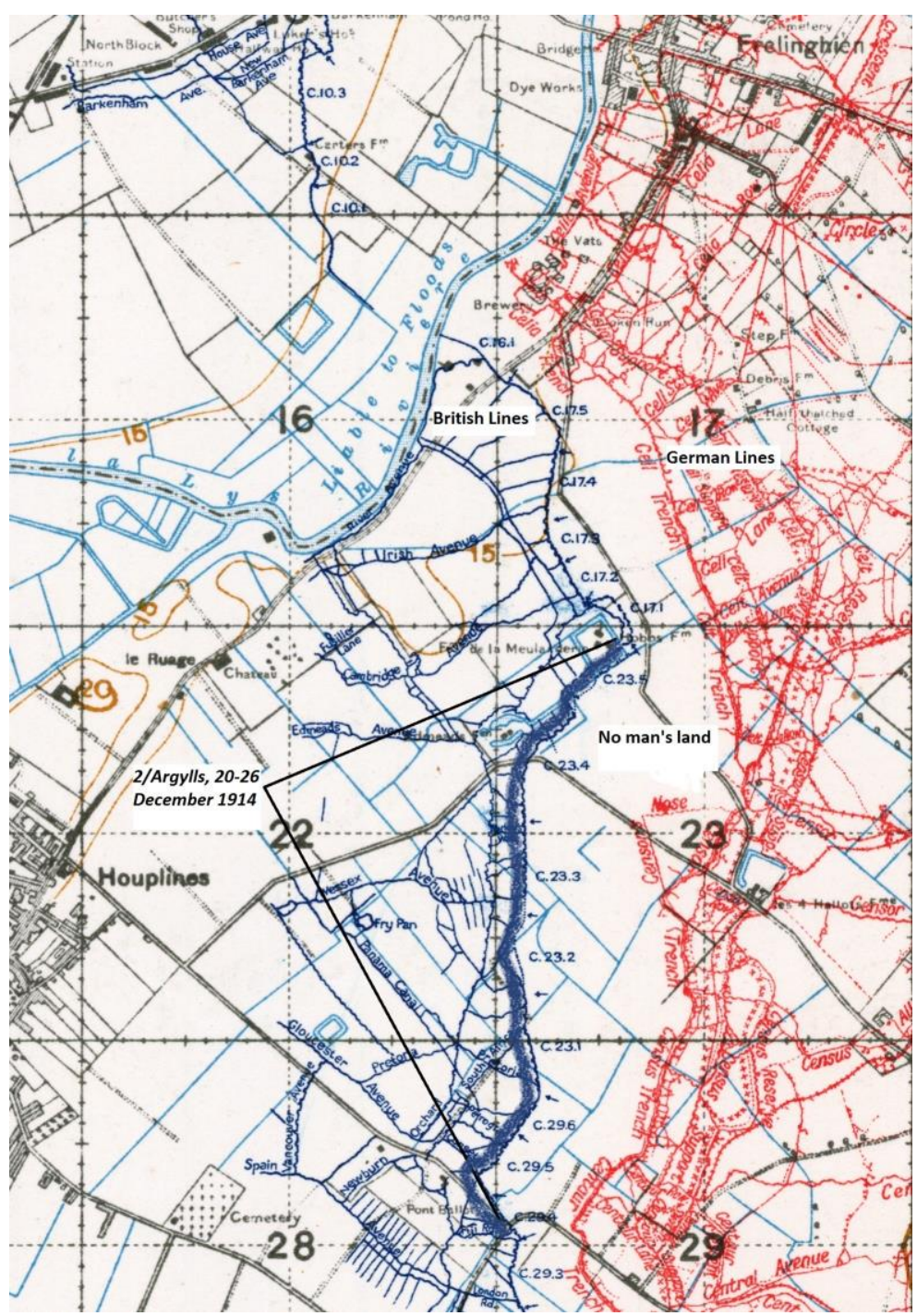

Figure 2 The 2/Argylls manned the trenches from Pont Ballot in the south to Hobbs Farm in the north. Reproduced by permission of the National Library of Scotland. 
The next three days were relatively quiet despite receiving orders that 'active sniping to be practiced and sapheads pushed on'. ${ }^{22}$ During the day, the Argylls received a message from GHQ that sought to develop suspicions of enemy behaviour and discourage fraternization; 'it is thought possible that the enemy may be contemplating an attack during Xmas or New Year and special vigilance will be maintained during these periods'.23

On the evening of December 24 the 133/Saxons left their billets in Pont Rouge and Frelinghien to take up positions opposite the 2/Argylls. ${ }^{24}$ Like GHQ, the German headquarters warned their troops to be alert against possible attack over the holiday period. However the 133 were not going to be deprived of their celebrations and Lieutenant Klemm's section took two small Christmas trees with them, complete with candles, to put on the trench parapets. ${ }^{25}$

Klemm commented that 'as was usual at that time, having settled in the trenches, we fired the occasional shot from our outposts to let the enemy know we would not let ourselves be surprised. ${ }^{, 26}$ Once these formalities were over the trees were placed upon the parapets and the candles lit; Klemm noticed that Christmas trees were appearing along the German line as far as the eye could see. His battalion colleague, Oberstleutnant Niemann, remembered placing one small tree in their company dugout and another on the parapet and then the troops began singing Christmas songs, such as Stille Nacht, Heilige Nacht, and $O$ du Fröbliche. ${ }^{27}$ The powerful German Christmas Eve tradition of singing and drinking by a candle-lit tree was carried over into the trenches.

The sounds of the Germans singing carried across to the trenches opposite and the Argylls' commanding officer, Captain Hyslop, recorded: 
In the evening ... the Germans had a sing-song in their trenches, they

even seemed to have a band of sorts somewhere near. One man had a

fine tenor voice, and as our men could hear quite well they applauded

the song, and he gave an encore. ${ }^{28}$

Hutchison noted a 'German band in the trenches. We sang in turns - Germans and ourselves'. Niemann reminisced that soon the British sang too and he noted particularly 'It's a long way to Tipperary' and 'Home Sweet Home'. ${ }^{29}$

After much bantering across No Man's Land, it was finally agreed that two men from each side should go out and meet. Nineteen year old Lieutenant Ian Stewart, at that point the youngest officer in the BEF and who could speak some German, went out from the Argylls, accompanied by Sergeant Minnery; Stewart noted that the conversation was rather like meeting a fan of an opposing football team. He received a cigar, which made him feel sick, and a photograph of the Saxon regiment's pre-war football team (Figure 3). In return, he gave the German officer, a man of about his own age and with a similar level of English to his German, a tin of bully beef. ${ }^{30}$

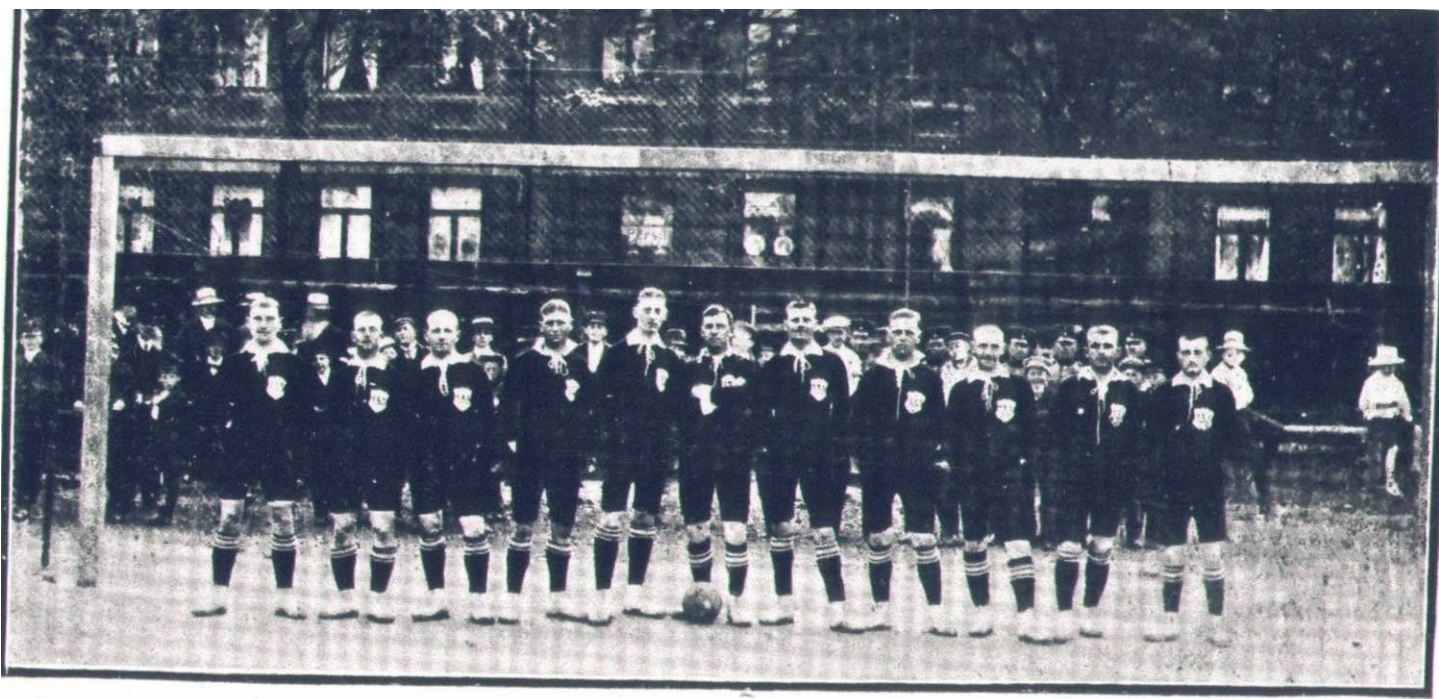

Copy of photo presented to Lt. I. M. Stewart by an opposing German Officer between the Lines on Christmas Day, 1914, on the occasion of the "unofficial armistice."

The photo is of the pre-war football team of the 133rd Saxon Regt. who were in the trenches opposite to the 93rd at the time.

Figure 3 Photograph of the 133 Royal Saxon Regiment pre-war football team.

Courtesy of The Argyll and Sutherland Highlanders Museum, Stirling Castle. 
Meanwhile, Minnery chatted with the other German, Enno Schneider, and discovered that Schneider knew Glasgow well. Minnery exchanged his woollen hat and a photograph of himself for a cap badge and chocolates. ${ }^{31}$ After agreeing it was a 'beautiful night', they shook hands and departed back to their own trenches. Hutchison recalled it was a relaxed night, 'much shouting. On the qui vive all night'. ${ }^{32}$ The Argylls' War Diary for Christmas Eve simply recorded 'Work carried out on communication trenches. A new one made from C Company Line. Brig. Gen. Congreve $16 \operatorname{Inf} \mathrm{B}^{\mathrm{de}}$ visited trenches before taking over on $26^{\text {th }}, 33$

\section{Christmas Day}

The stories of Christmas morning vary slightly; Frederick Chandler, the Argylls' Medical Officer, Hutchison, Liddell and Hyslop describe shots being fired in the morning but 'in the afternoon a curious thing happened, for the sniping suddenly ceased'. ${ }^{34}$ The German officers, Klemm and Niemann, thought that at dawn they became aware of heads popping into sight above the British parapet and peering into No Man's Land. ${ }^{35}$ Klemm noted that somebody needed to break the ice and an NCO from his company took a Christmas tree into No Man's Land where he was met by a British soldier. After these soldiers returned to their own lines, further shouted negotiations occurred about the bodies that lay between the trenches following a battle in November. Eventually Lieutenant Grosse, Klemm's platoon commander, met with a British officer and they agreed to bury the bodies behind their respective front lines. $^{36}$

The burial parties fraternised as they worked and the soldiers left in the trenches began calling across No Man's Land to each other. They soon 'arranged an unofficial armistice - they got out of their trenches and met halfway and hobnobbed with each other, exchanged souvenirs and had drinks ... Stewart, had a box of good cigars given 
him.' Klemm received a cap badge from a British soldier and noted 'everywhere you looked the occupants from the trenches stood around chatting to each other and even playing football.' Niemann, as described above, recollected that later a Scottish soldier brought out a football and 'a real football match got underway., ${ }^{37}$

There are no British descriptions of this game but Private Collier of the Argylls recalled 'some of the men in the Platoon on our left had made a "ball" from paper, rags and string and went their "dinger" for about twenty minutes, until the ball fell to pieces and that was that. ${ }^{38}$ Hyslop, Liddell and Hutchison all recorded that the German officers were keen to arrange a proper football match for the following day, December 26.

As evening approached, Hyslop reported 'altogether the men were out of their trenches for nearly two hours, but we parted before dark and the last words of a German officer were "Well, it will be war again tomorrow.",39 According to Hutchison, GHQ heard about the truce and ordered 'warlike measures against the enemy must be adopted forthwith'; he wrote a letter to the Germans telling them 'war will be declared at 10 a.m. to-morrow morning.' A German NCO took the letter 'presumably to the officer commanding the $134^{\text {th }}$ Saxon Regiment'. 40

Figure 4 shows the view today from Pont Ballot, where Liddell, the battalion machine-gun officer, had established a machine gun post, north towards Hobbs Farm which was about 1,000 feet beyond the modern Massey Ferguson dealership in the distance. The British lines snaked along just to the left of the centre of the image with the German lines towards the right hand edge. The fraternisation and any football would have been in No Man's Land in this field. ${ }^{41}$ Of Christmas Day, the Argylls' War Diary records a 'very quiet day. Germans came out of their trenches unarmed in the afternoon, and were seen to belong to the $133^{\text {rd }}$ and $134^{\text {th }}$ Regiment. The position 
was reconnoitred by Lieut. Anderson. The Germans asked for leave to bury 10 dead.

This was granted. ${ }^{, 42}$

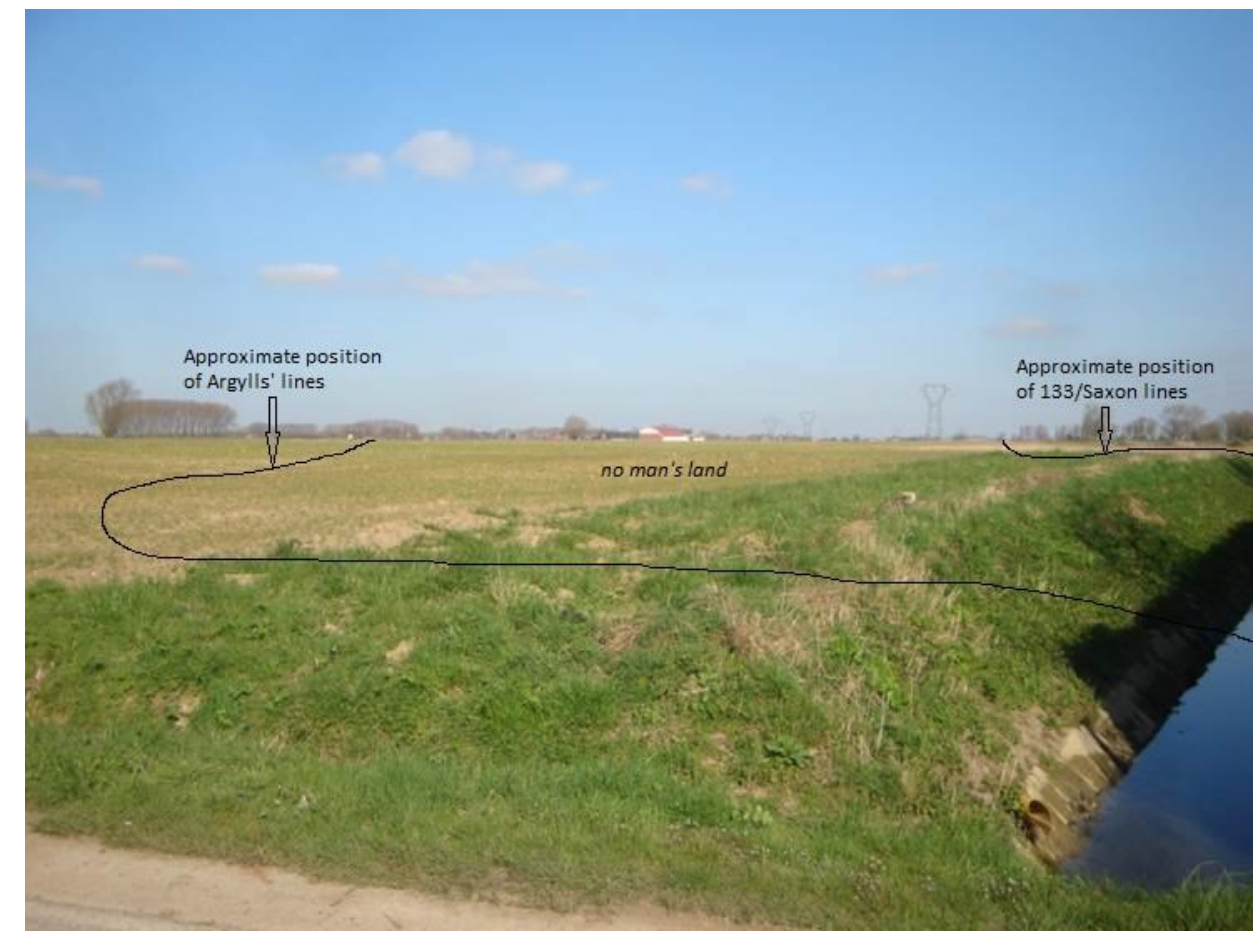

Figure 4 View from Pont ballot towards Hobbs Farm. Author's photograph, 16 March 2014

\section{December 26, 1914}

After spending the day in the trenches, the Argylls were relieved by the Sherwood Foresters at 17:00. ${ }^{43}$ The formal proposed football match had not occurred either because of senior officers' actions or shelling. Captain Jack of the 1/Cameronians in the trenches that abutted the 2/Argylls at Pont Ballot observed:

It seems that on Christmas Day the 2/Argyll and Sutherland actually arranged to play a football match versus the Saxons - whom we consider to be more human than other Teutons - in No Man's Land that afternoon. Indeed someone in my trench told me of the proposal at the time, but I scouted so wild an idea. In any case, shelling prevented the fixture. ${ }^{44}$ 
Hutchison recorded that there was a 'good deal of artillery fire in the morning. In the evening the whole Brigade relieved'. ${ }^{45}$

\section{Aftermath}

Initially there was widespread doubt that any truce had occurred over the Christmas period, but the evidence of photographs, diaries and letters is overwhelming and some of the photographs and letters appeared in the press; at that time censorship of soldiers' mail home was still developing. ${ }^{46}$ Truces did not occur all along the AngloGerman lines; today it is estimated that there were various levels of fraternization along about two-thirds of the British sector. Even the immediate neighbours of the Argylls, the 1/Cameronians had no truce; in his diary Jack wrote 'there are extraordinary stories of unofficial Christmas truces with the enemy ... There was no truce on the front of my battalion. ${ }^{47}$ Altogether 81 British soldiers died on Christmas Day, and on December 26 there were a further 62 British deaths; no doubt some of these were from previously received wounds.

It has been proposed that the truces may have been partly a result of new troops being introduced into the front, essentially civilians in uniform. ${ }^{48}$ However, it is evident that few new recruits, especially British, made it to the front until the spring of 1915 , although some individuals $\operatorname{did} .^{49}$ Perhaps it was the fact that, at this stage of the war, the armies were still mainly professionals and reservists (ex-professionals) that allowed the truces to occur. Collier remarked 'we were the same as them; after all we were all tradesmen in our own particular sphere - soldiering', 50 These troops would have had a mutual respect for fellow soldiers; they were probably significantly less influenced by state propaganda or the hell-fire preaching from pulpits and press than the new volunteers in training. Their nationalism and patriotism were different from the new more idealistic recruits. ${ }^{51}$ 


\section{Was there a game for Christmas?}

Brown and Seaton reported 'there are those, including some veterans of 1914, who doubt if any football match took place at all. ${ }^{52}$ A perusal of the War Diaries of all of the British infantry battalions that were in France on December 25, 1914 reveals that none of them mention football with the enemy. This is not surprising as the war diaries were kept by designated junior officers, who at this early stage of the war would have joined up before hostilities commenced and intended to make the army their career. They would have been aware of GHQs attitude to fraternisation, let alone unofficial truces, and therefore it may be surmised that the incidents were probably far more numerous than reported. According to Jürgs, the same is true of Regimentstagebuchern, German regimental records, as their High Command also tried to prevent fraternisation. ${ }^{53}$ However, judicious editing by battalion commanders may have also occurred; the war diary of the $1 /$ The Buffs (East Kent) is missing the pages for December 21-29. Private Deakins of The Buffs recalled 'The Germans came out of their protective holes, fetched a football, and invited our boys out for a little game. Our boys joined them and together they quickly had great fun, till they had to return to their posts. ${ }^{54} \mathrm{Did}$ an incautious diarist record the incident leading to the commanding officer ripping the offending pages out?

The two 133/Saxons' officers', Klemm and Niemann, stories are essentially similar with Niemann's post-war history of the battalion reporting soldiers of both sides chasing hares amongst the cabbages and then playing football. ${ }^{55}$ None of the British officers of the 2/Argylls mention playing football but all agree that an 'international' match was discussed. Football was endemic in the BEF by the end of 1914 and so, possibly, such a normal occurrence as an informal kick-about by soldiers 
was not worth writing about, but the planning of a more formal 'international' game was certainly worth reporting. ${ }^{56}$

Trench warfare had rapidly led to an increase in footballing opportunities for the British troops. Officers encouraged their men to play; 'we did seventy-eight hours on end in the trenches last spell. This morning we had a football match. Football is the only thing that takes the stiffness out of the men after being long in the trenches'. Hutchison noted that the villages behind the front lines 'bore the semblance almost of English villages, packed with lads playing football'. The Cameronians' Captain Jack noted in his diary that when in reserve around Christmas 'games, mainly football, in the afternoons keep them fit and cheery ... however tired the rascals may be for parades they have always energy enough for football.' Football tournaments began to be organized from platoon to divisional level and in July 1915 General Haig complained about the number of men falling asleep on sentry duty; 'men should rest during the day when they know they will stand on sentry duty at night. Instead of resting they run about and play football'.57

Both the 2/Argylls and 133/Saxons contained keen footballers and the Scots already had an illustrious footballing history. In the main, the other ranks of the Argylls were from the Scottish working classes and football was their dominant sport. The Army Football Association had established the Army Cup in 1889 and the 2/Argylls won the inaugural competition beating the 2/South Staffordshire's 2-0 in the final and they were the beaten finalists in 1891. When based in India and South Africa between 1892 and 1910 the battalion won several football tournaments including the South African Army Championships of 1908 and 1909. ${ }^{58}$

Thermaenius identifies 1885 as the starting point for football in Zwickau where the 133/Saxons were based. High school students began playing and forming 
neighbourhood teams and the game developed rapidly in Saxony following the success of the Leipzig team. In 1914 Fussballclub 02 Schedewitz from Zwickau lost 18 players to the army forcing them to field only one team instead of the three in the previous season. Thermaenius opines that many of these 18 would have been reservists attached to the 133 as this was the regiment in which local men would have completed their two years national service. Stewart commented that the officer who gave him the photograph of the pre-war football team seemed to be very proud of it. Alfred von Kotsch, the commanding officer of the 133 at the beginning of the war, noted that one of the duties of the support troops was to organise football tournaments for the troops as they came out of the front line. ${ }^{\mathbf{5 9}}$

Apart from Collier's reported kick-about, other reports of football possibly involving the 2/Argylls emerged. The Glasgow News of January 2, 1915 published a letter from a Highland Regiment officer who had met with a Saxon Regiment and claimed that 'we arranged ... to have a two hours interval on Boxing Day, from 2pm to $4 \mathrm{pm}$, for a football match. This, however, was prevented by our superiors at headquarters'. Another letter in the same paper from a 5/Scottish Rifles' Sergeant stated he was guarding the communication trenches that led to the front line and had heard that 'Some of our boys (the Argyll and Sutherland Highlanders) visited the Germans in their trenches, wished them a Merry Christmas, and agreed to have a truce for 24 hours. They also had a football match between the two lines of trenches and exchanged gifts of cigars and chocolates'. ${ }^{60}$

The ILN of January 8, 1915 reported 'some of the British, it is said, visited the German trenches, and an Anglo-Saxon football match was even played' and on New Year's day, The Times published a letter from a major of the RAMC 'The ----Regiment actually had a football match with the Saxons, who beat them 3-2!!!' Lance 
Corporal Prince of the North Staffordshire Regiment located just to the south of the Argylls noted that 'further up the line, I caught a glimpse of what looked like a more formal game of soccer between the two sides'. ${ }^{61}$ 'More formal' is interesting as it intimates kick-abouts were occurring there too.

Much of the evidence of the various truce activities, including football, is heavily dependent upon soldiers' letters home. However as Richard Holmes observed: It is temptingly easy for historians to regard the first-hand accounts written or oral - of survivors as the pure and undiluted truth. Such is rarely the case. Even when events are recalled shortly after they have happened, memory still plays tricks, with snatches of experience being collated in a haphazard order, like clips of film assembled at random from the cutting-room floor. There is a natural tendency for the mind to shut off the most ghastly episodes, and the stress of battle itself interposes a filter between an event and its observer ... And there are other problems. Most front-line soldiers in most wars live on a diet of rumour intermixed with partly explained facts. ${ }^{62}$

Volunteer driver Frederick Coleman's description of finding a platoon officer hard at work censoring his men's letters home supports Holmes' observation. The censor showed Coleman one letter describing how the author had escaped death and injury miraculously several times even from a 'black Maria' that had burst close to him. ${ }^{63}$ However, the author of the letter was the regimental farrier who was not allowed anywhere near the front! When the censor asked the other officers what he should do the whole mess replied in chorus 'Pass it ... It will do no harm.' Some weeks later the censor showed Coleman that the letter had been published in a local Midland newspaper exactly as sent to the farrier's mother. The farrier kept up the good work 
and all the mess looked forward to the next letter as 'not a week passes he doesn't curdle the blood of the old folks at home with some yarn. We quite look forward to 'em. The paper fairly eats 'em'. ${ }^{64}$

Certainly as news of Christmas truces spread amongst the troops some 'tall' stories emerged. Private Elvin of the 2/Suffolk's wrote that his 'regiment did not play the Germans at football on Christmas Day, or shake hands with them' although 'some of the men of Wisbech wrote and said they did. ${ }^{65}$ In a letter home a private from the 4/Seaforth Highlanders mentions beating the German 4/Saxon regiment $6-2$ on Christmas Day, but another private in the same battalion in a letter published in the Football Times of January 9, 1915, wrote 'On Christmas Day we hoped to have a rest, but no luck. We have marched about ten miles away from the lines' which agrees with their War Diary that notes the battalion marching to Robecq, 10 miles west of Vielle Chapelle and does not record any soldiers being detached to other units. ${ }^{66}$

It is possible that knowing that letters home were being published, some soldiers may have wished to exaggerate dangers to increase their standing amongst their relatives and friends at home. However, Hugo Klemm's letter was to his regimental comrade-in-arms Johannes Niemann and they would have shared the memories so it is doubtful that he would have made up remembering 'everywhere you looked the occupants from the trenches stood around talking to each other and even playing football' ${ }^{67}$

\section{The case against football}

Some commentators believe that No Man's Land was too cratered to allow football and that may have been the case in some areas. Private Runcie of the Gordon Highlander's wrote: 
Some chroniclers of the truce incident have claimed that a football match was played in No Man's Land; but this is not the case as the shell-holes, ditch, barbed wire, and churned-up condition of this part of the ground rendered it impossible to do so. ${ }^{68}$

However where the Argylls and 133/Saxons faced each other, soldiers described No Man's Land as a meadow or as an overgrown cabbage field. Aerial photographs taken by 4 Squadron, Royal Flying Corps, of the Houplines trenches in July 1915 and March 1916 reveal few shell holes in No Man's Land and these would not have prevented kickabouts. ${ }^{69}$ Today the collective image of No Man's Land is coloured by Passchendaele of 1917 when the ground had been subjected to years of shelling and the artillery had become significantly heavier and more numerous. Others point to the mud which prevented easy movement, but the rain had turned to snow on December 23, and December 24 brought a hard frost transforming the front, the mud hardened and pools froze. Lieutenant Bolton of the Argyll's found that his kilt floated around his waist in the trench and then froze. He hacked it off and replaced it with sandbags. ${ }^{70}$ Certainly photographs of the truces show the soldiers standing on the surface rather than sinking in mud and their surroundings are not overly shell pocked and Niemann had remarked that 'it was far from easy to play on the frozen ground'(Figure 5)..$^{71}$

Other commentators note that footballs would not have been available in the trenches as the men's kit would not have let them carry something so cumbersome. However football was pervasive in the BEF and balls were valuable, although by 


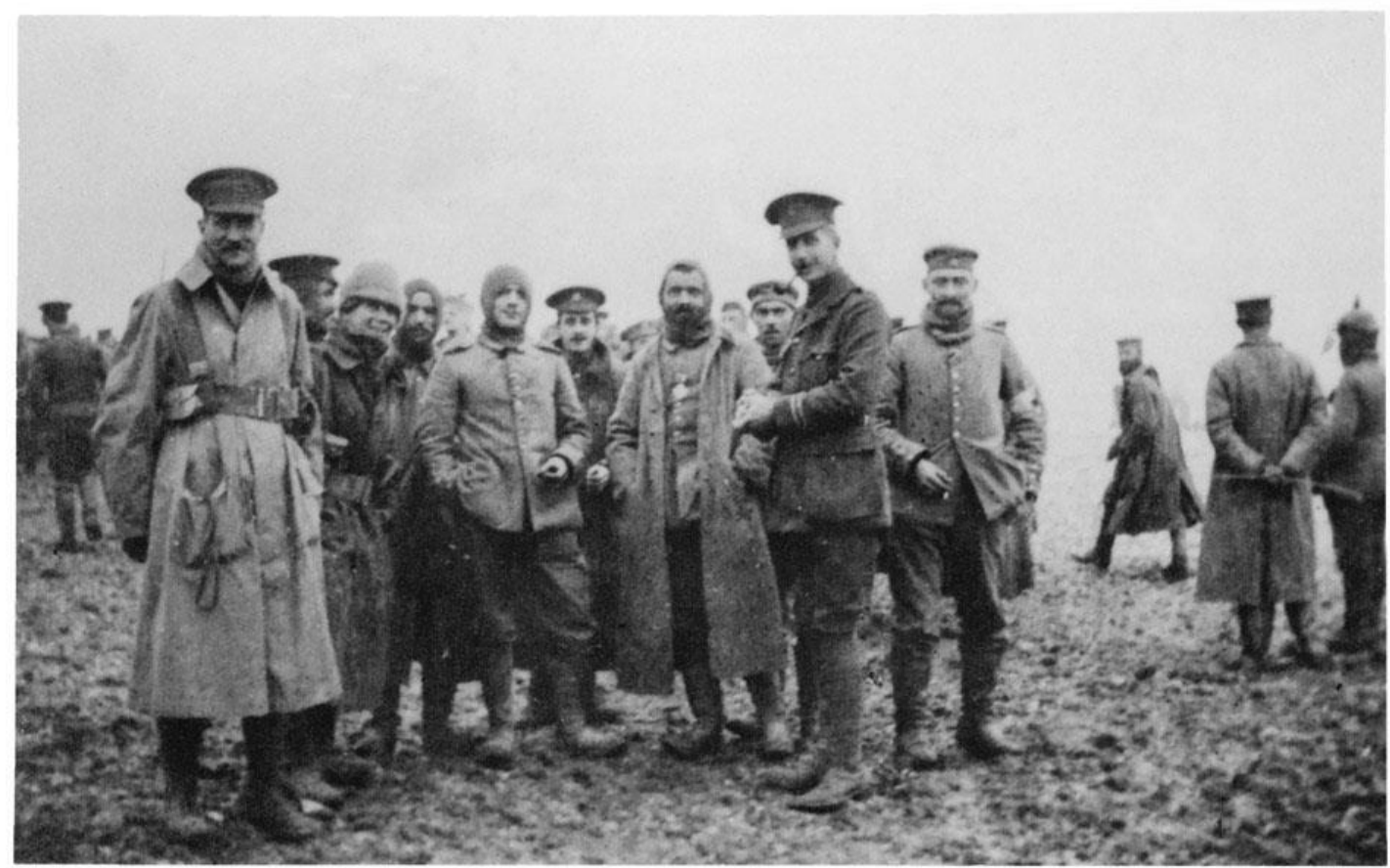

Figure 5 British troops from the East Surrey Regiment meet German opponents. Photograph by Lt. Col. A.F. Logan. CNational Army Museum (NAM 1995-06-89-1-1).

1917 every platoon would have its own. Therefore it is likely that soldiers who had a ball would have deflated it and carried it with them, rather than leaving it in their billets, where the next regiment may have purloined it, or in their valises in battalion transport. By carrying it with them, they were ever ready for a game when in reserve. The reserve trenches were often out of sight of the enemy and, when not on 'fatigues' or 'stand to', men were sometimes allowed free time in close proximity to their positions. The Cameronians' medical officer later noted 'the French are always fascinated by the British obsession with football, asking why so many soldiers carry balls strapped to their packs. Here is the answer - they are waiting for Christmas' ${ }^{72}$ Stories of what men managed to take into the trenches are legion; a deflated football would certainly take less space than an accordion (Figure 6). Certainly in the football charge at the Battle of Loos, the men of the London Irish smuggled their deflated 


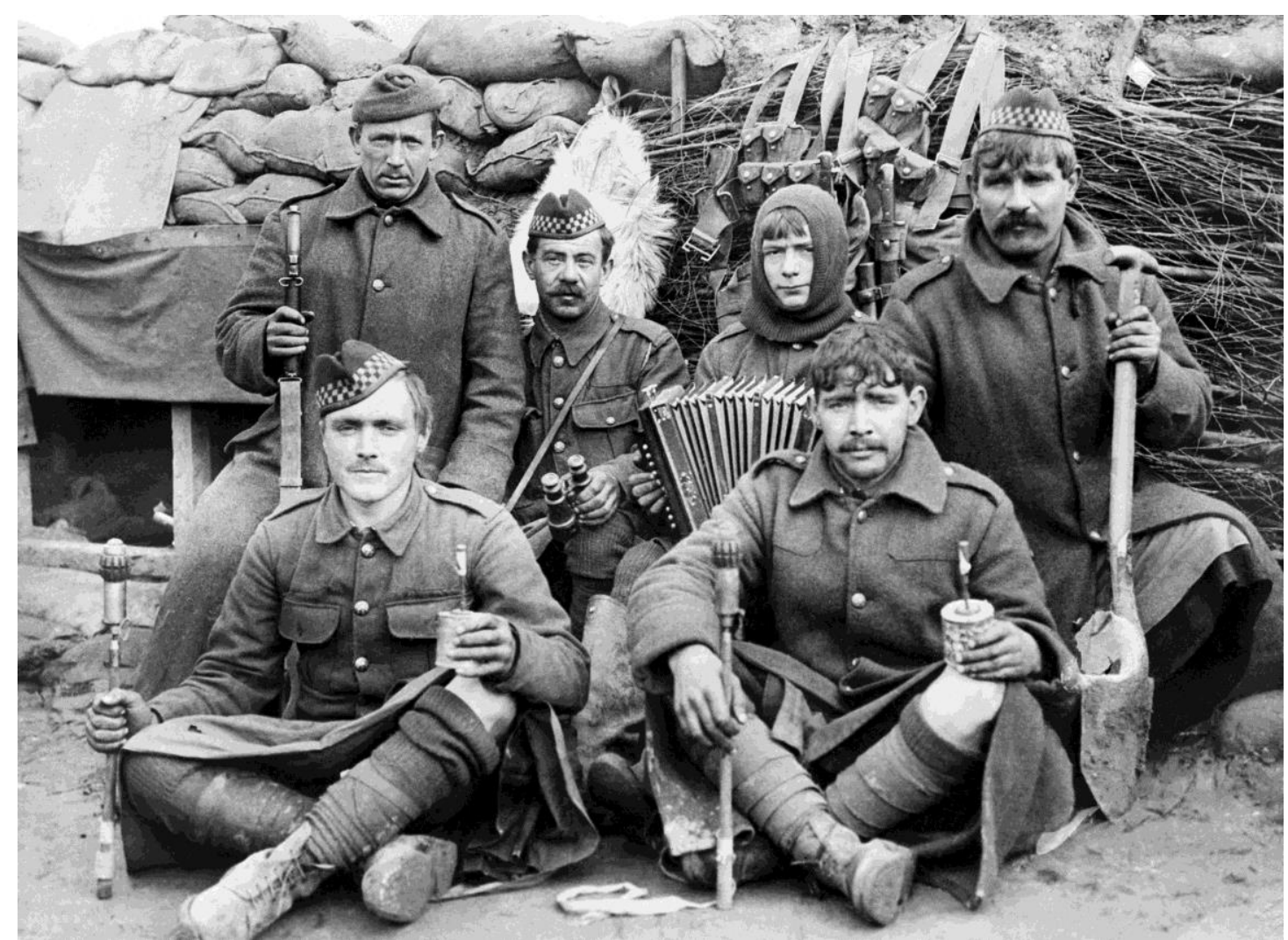

Figure 6 2/Argylls with home-made jam jar grenades and accordion. Photograph by

Capt. A. Bankier. OImperial War Museum (Q 48958)

footballs into the trenches after their officers objected to their plan of dribbling the balls forward in the charge. ${ }^{73}$ Modern analysts forget that the balls of the time did not have valves requiring special inflating needles; they could be blown up by mouth.

Also it is certain that some soldiers would have received a football for Christmas and Niemann intimates that a real ball was used. For example, Private Rivett of the 1/Lincolnshire wrote a letter to his wife, published by The Grimsby Daily Telegraph of January 3, 1915, explaining that on Christmas Day he had been in battalion reserve just behind the firing line and 'we had football matches with a new ball sent by some kind friends' ${ }^{74}$

Pre-Christmas British and German newspapers had carried adverts reminding readers of the needs of the men at the front and a veritable avalanche of parcels arrived at both sides of the front. Between December 6 and 12, 250,000 parcels were sent to the British troops at the front along with 2.5 million letters. ${ }^{75}$ Hutchison's diary 
records that on December 21 'Xmas gifts pour in from all round the countryside' and Percy Jones of the Queen's Westminster Rifles wrote in a letter home 'I am keeping well, in spite of the large number of Christmas parcels received. ${ }^{76}$ Some battalions report Christmas parcels being delivered into the firing line and it is highly probable that some would have received footballs. Even if only one percent of the men received a football, this would place at least six or seven new balls into a front line battalion that received packages. The German soldiers were equally inundated, causing Niemann to note that they marched to the trenches 'like Father Christmas with parcels hanging from us. ${ }^{, 77}$ One of Percy Jones' colleagues, Lance-Corporal Jack Quayle, wrote that when the early morning fog rose on Christmas morning, the Germans were observed playing football. Another member of the same battalion had a letter published in both London and New York which claimed 'On Christmas Day we had a football out in front of the trenches and asked the Germans to send a team to play us but either they considered the ground too hard, as it had been freezing all night and was a ploughed field or their officers put the bar up. ${ }^{78}$

Some of the arguments about whether football was played or not may lie in philosophical differences about what 'playing football' means. To some playing football means two goals, a large flat surface, a referee and a proper football. To others it may simply be any playful activity involving kicking an object around. Private Collier recalled soldiers playing with a 'ball' of paper, rags and string, and there are other reports of 'balls' of straw stuffed balaclavas, sandbags and tin cans being used at Christmas between the lines. ${ }^{79}$ General Latter, a young officer with the Lancashire Fusiliers in 1914, recorded an unofficial truce on Christmas Day with the Saxons opposite and "'A" Company played a football match against the enemy with 


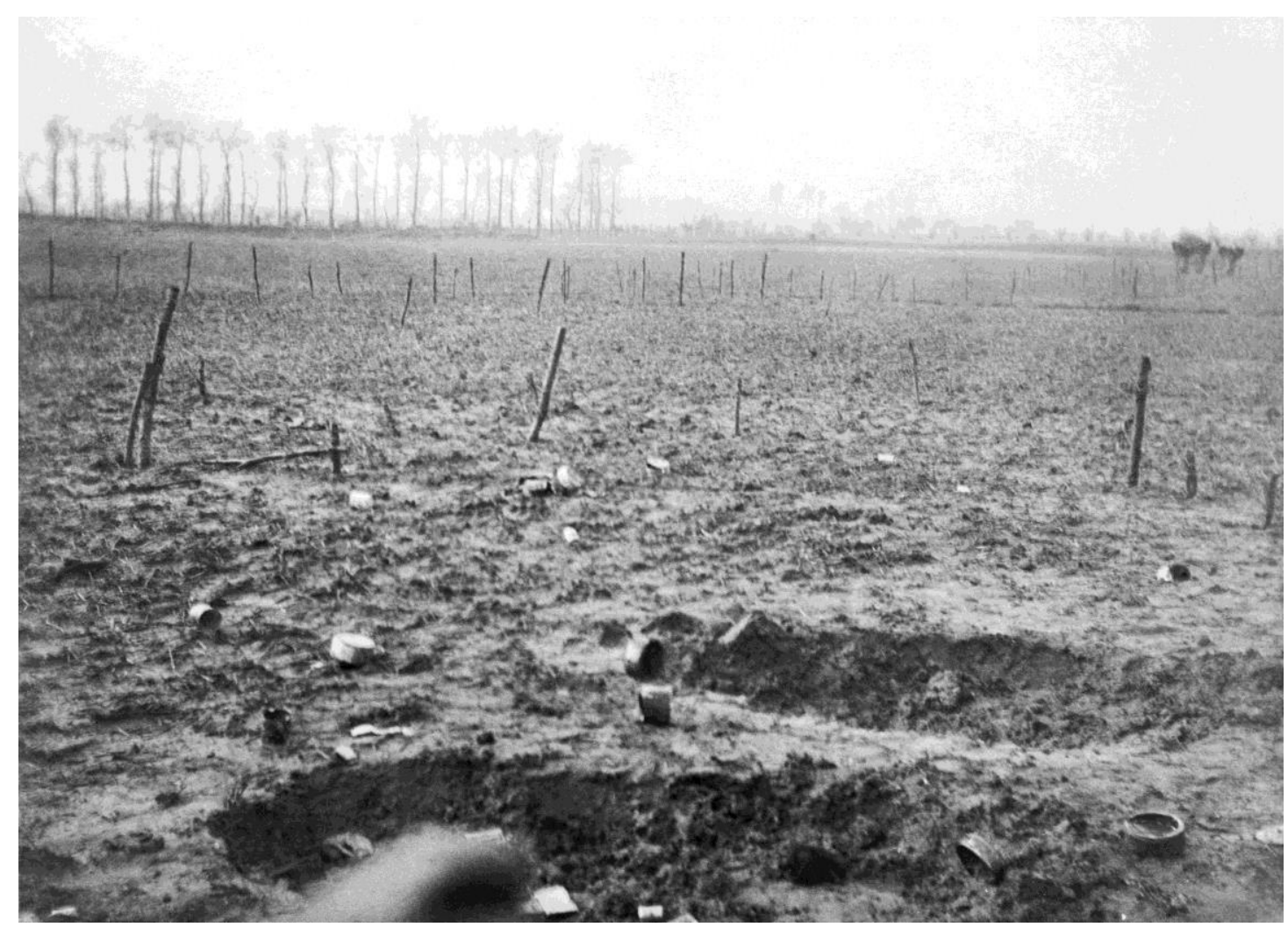

Figure 7 View across No Man's Land, La Boutillerie, winter 1914-1915. Photograph by Col. A. Bruce. CImperial War Museum (Q 49102)

an old tin for a ball; they won 3-2!' although Lance Corporal George Ashurst with the same unit remembered 'Some of our boys tied up a sandbag and used it as a football, while a party of Germans enjoyed themselves sliding on a little frozen pond just in the rear of their trenches'. ${ }^{80}$ Photographs of the British wire (Figure 7) show the area immediately in front of the firing trench strewn with empty tin cans. These certainly contributed to the rat problem but were hoped to provide some warning of an offensive German party creeping up at night.

Perhaps one of the most evocative stories of football at Christmas 1914 involves a non-regulation ball. Second Lieutenant Brockbank joined the 6/Cheshires on December 11; his first trench experience began when they entered the front line near Messines on December 22. His diary entry for Christmas Day records: 
At about 2.30 (p.m.) all firing ceased and the Germans started shouting to us 'Come out' 'Have a drink' and then one of them climbed out of the trench without his equipment on, so one of ours did the same. It ended in a 'Mother's Meeting nearly every man of our trench, except machine gunners, was out, \& a huge crowd was between the trenches. Someone produced a little rubber ball so of course a football match started. We exchanged various things \& I got a cap-badge, belt buckle, whistle, rifle cartridge purse and tea tablets, not to mention getting about four Germans names and addresses in their own handwriting on field service postcards, as a positive proof that it all really did happen, because it will naturally sound a very tall story when it gets told in the billets. ${ }^{81}$

The 'so of course a football match started' highlights the omnipresence of football in the BEF and British society and the likelihood of kickabouts wherever and whenever the opportunity presented itself. ${ }^{82}$

\section{Conclusion}

Many regard Christmas 1914 as the close of the nineteenth-century, the inevitable result of fin de siècle cynicism. Truces were a time-honoured courtesy, wars were fought against opponents rather than enemies and there had to be 'fair play.' January 1915 saw Zeppelins indiscriminately bombing London; gas was introduced as a deadly weapon in April, the Lusitania was torpedoed in May and July marked the first notable use of flamethrowers. The twentieth century had arrived and, in essence, Christmas truces were history as the German quest for modernity brought the reality of industrialized war into sharp focus and into direct conflict with the British quest for restoration and preservation of the status quo. 
Some commentators opine that it is possible that the truce was a manifestation of some of the soldiers' frustration at an apparently meaningless war in which they were trapped; the truces represented a small gesture against the rising tide of international and nationalist rivalry and hatred, a demonstration of the brotherhood of man or a symbol of the deep religious significance of the time. ${ }^{83}$ However, the letters and diaries of many of the soldiers reveal that they knew that a set of circumstances had given them the opportunity for a welcome break in five months of war, in essence a holiday. To others it was a schoolboy prank against the prefects and school masters. Lieutenant Drummond of the Royal Field Artillery said it was 'a soldier's truce without any higher sanction by officers and generals. ${ }^{84}$ Whether they regarded the truces as a prank or welcome holiday; the soldiers recognised that the conflict had purpose and meaning even if they might disagree with its management. They expected to continue and win by spring. Many officers, still mainly from a different social class from their men, may not have been motivated to write about an unruly pick-up game of football. If no football was played then the rumours of it being played and the expressed desires to play reveal a lot about the culture of the soldiers.

Football was ubiquitous behind the lines once siege warfare dominated the Western Front, especially on the British side. Sports newspapers were sought after and even thrown across to the Germans so they could follow their favourite British teams. It was a common topic of conversation between soldiers on both sides of No Man's Land and even across it as the English professional season continued until the Khaki Cup Final of April 24, 1915. The language of the soldiers was infiltrated by football; Henry Williamson's alter ego Philip Maddison noted that No Man's Land at 'first sight looked like a crowd on a football field during the interval of a match.' Private Hunter of the 2/Monmouthshire's was told by a German during the truce that 
he would 'much rather be having a game of football than this' (the war). Another German complained about how the war was interfering with his football as he had played for Leipzig. ${ }^{85}$

With thousands of young men standing around in No Man's Land on Christmas Day unable to really converse with each other once impromptu sign languages were exhausted and trinkets exchanged, somebody would have kicked something, and somebody would have kicked it back. Then, perhaps somebody would have hurried to inflate a ball received for Christmas or carried in their packs.

It is certain that soldiers did not play a football match in No Man's Land with stretchers for goalposts and the padre declaring Captain Blackadder offside, but with so many young men milling around, kickabout games of football with tin cans, paper wrapped with string, straw stuffed balaclavas, or perhaps with a real ball, inevitably occurred, the players cheered on by their brother soldiers.

The micro-myth of football during the Christmas truces of 1914 was publicly commemorated with the unveiling of a memorial by Prince William at the National Memorial Arboretum on December 12, 2014. The design was chosen after a national competition, Football Remembers, sponsored by the British Council, the Premier League, The Football Association and the Football League. ${ }^{86}$ The Football Remembers project also held an international mass-participation event through the Embassy network and presented a 'living statue' to the Belgian city of Ypres in the form of a new $3 \mathrm{G}$ football pitch where an annual international youth Christmas Truce tournament has been held since 2011; 'The Christmas Truce tournament is a key part of the Premier League's Elite Player Performance Plan, which develops players not only with their tactical and technical skills but also caters for their educational and cultural needs.' The 2014 tournament featured Under-12 teams from England, 
Germany, France and Belgium and before it began the England boys visited 'the Christmas Truce site, where in 1914 an unofficial truce took place in the trenches around Ypres which ended up with reports of a football match being played in No Man's Land.' In May 2014, in preparation for the events, more than 30,000 schools in Britain 'received an educational pack about the moment in history when football brought war to a halt' ${ }^{87}$

On December 11, 2014 Michel Platini, President of UEFA, European football's governing body, unveiled a new memorial to the Christmas Truce next to the Commonwealth War Graves Commission's Prowse Point cemetery. The memorial has the inscription "To all those who experienced the "Small Peace" in the "Great War"'. Gilbert Deleu, the local Mayor, commented: 'By putting the seal of UEFA, and of this popular sport that is football, on these commemorations, Michel Platini has in one stroke called up all those who love the 'round ball' to take possession of this truce and propagate its spirit and the hope that it has provoked. ${ }^{98}$

Stephen Moss of The Guardian newspaper wrote on December 16, 2014:

In this centenary year, the truce is ubiquitous. Sainsbury's made it the centrepiece of its Christmas ad campaign, following the narrative laid out by Paul McCartney in 1983 in the video for his hit single Pipes of Peace ... The McCartney take on history has hardened into orthodoxy.

The centennial commemorations have reinforced the belief, amongst many, that there was a general truce along the whole front line on Christmas Day rather than various levels of fraternisation along some two-thirds of the British line organised at the local level. Similarly 'popular imagination' seems to assume that a semi-formal match occurred during the Christmas Truce; 'The football match spontaneously broke out in No Man's Land'. ${ }^{89}$ However many, including historians, know that if any 
football was played it would have been in the form of improvised kickabouts and many websites, including some pages of Football Remembers, do mention football games (plural) away from their headlines.

Despite the uncertain narrative surrounding football and the Christmas truces, British football organisations have managed to re-present the story 'polishing' their cultural credentials and further legitimating the place of football in the "collective memory'.90

\section{Notes}

${ }^{1}$ Robert Hands, 'Preface: They Also Served: Re-evaluating and Reconsidering the Neglected', The International Journal of the History of Sport 28 (3-4) (2011): 429-434, 430-431; Wray Vamplew, 'Exploding the Myths of Sport and the Great War: A First Salvo', The International Journal of the History of Sport 31.18 (2014): 2297-2312.

${ }^{2}$ Malcolm Brown and Shirley Seaton, Christmas Truce: The Western Front, December 1914 (Basingstoke and Oxford: Pan, 2001), 134. The implied emphasis on the definitive article 'the' by Brown and Seaton was quite prophetic with regard to the media coverage of the 2014 commemoration of the Christmas truces.

${ }^{3}$ Emma Hanna, 'Myth \& Reality: The Christmas Truce, 1914', The Western Front Association Bulletin 101 (March 2015):12-13.

4 'Duke of Cambridge kicks off "Football remembers", cambridge-kicks'football-remembers' [accessed 12 October 2014].

${ }^{5}$ Nick Hopkins and Richard Norton-Taylor, 'Kickabout that captured futility of First World War to be replayed for centenary', The Guardian, 8 February 2013. Many other newspapers and media outlets carried similar stories.

${ }^{6}$ This quote was later published in Lynn MacDonald, 1914-1918: Voices and Images of the Great War (London: Michael Joseph, 1988), 46-47.

${ }^{7}$ Iain Adams and Trevor Petney, 'Germany 3 - Scotland 2: No Man's Land, 25 $5^{\text {th }}$ December 1914: Fact or Fiction', in Alan Tomlinson, Alan Bairner, and Jonathon Magee, eds, The Bountiful Game? Football Identities and Finances (Oxford: Meyer \& Meyer Sport, 2005)

${ }^{8}$ Brown and Seaton, Christmas Truce; Stanley Weintraub Silent Night: The Remarkable Christmas Truce of 1914 (London: Pocket Books, 2002).

${ }^{9}$ Holger H. Herwig, First World War: Germany and Austria-Hungary 1914-1918 (London: Arnold, 1996), 249.

${ }^{10}$ David Stevenson, 1914-1918: The History of the First World War (London: Penguin, 2004).

${ }^{11}$ Stevenson, 1914-1918; Paul Fussell, The Great War and Modern Memory (Oxford: Oxford University Press, 2000).

${ }^{12}$ Martin Gillott, 'British Line Infantry Reserves for the Great War - Part 3', Stand To! The Journal of the Western Front Association, 102 (January 2015): 14-20 notes that British Army doctrine in 1914 expected $80 \%$ casualties in any campaign's first year; therefore it was expected the BEF would experience approximately 28,000 casualties by February 1915.

${ }^{13}$ Modris Eksteins, Rites of Spring: The Great War and the Birth of the Modern Age (Papermac: London, 2000); Peter Palmer, 'The Long March: the BEF in August 1914', The Western Front Association, http://www.westernfrontassociation.com [accessed 30 September 2014].

${ }^{14}$ At the outbreak of war more than half of the British army were on Empire duties overseas. Reservists were retired professional soldiers. Gillot, 'British Line Infantry Reserves' stated that on 16 December 1914 Sir John French complained that some of his reinforcements were over 50 years of age and had not fired a rifle since the South African War, 1899-1901. The Territorial Force was a home defence force and could not be compelled to serve overseas, 70 battalions volunteered to serve in France by the end of August 1914. 
${ }^{15}$ Eksteins, Rites of Spring.

${ }^{16}$ Graham Seton Hutchison, Warrior (London: Hutchinson, 1932), 47.

${ }^{17}$ Rudolf Binding, A Fatalist at War (London: George Allen \& Unwin, 1929), 35.

${ }^{18}$ David J. Fine, Jewish Integration in the German Army in the First World War (Boston: Walter de Gruyter, 2012), 43.

${ }^{19}$ Tony Ashworth, Trench Warfare 1914-1918: The Live and Let Live System (London: Pan, 2000).

${ }^{20}$ The drawing, although very detailed, omits barbed wire entanglements and, if the trenches were this shallow, higher parapets would have been constructed. Informal shooting matches are recorded although targets were hoisted from the trenches allowing the soldiers to remain in cover. Charles Lowe, 'The Great War', Illustrated London News, 26 December 1914, 890.

${ }^{21}$ Hobbs Farm was also known as 'Shelled out Farm' and marked where the Argyll's abutted the battalion to their north; to the south they adjoined the 1/Cameronians at Pont Ballot.

${ }^{22}$ War Diary, '2 Battalion Argyll and Sutherland Highlanders, $19^{\text {th }}$ Infantry Brigade', National Archives, WO 95/1365/1. Saps were trenches pushed into No Man's Land roughly perpendicular to the defensive trenches and often used as listening posts.

${ }^{23}$ Order from General Headquarters, Imperial War Museum PRO WO95/1440 and a December Appendix in several War Diaries.

${ }^{24}$ Hugo Klemm, 'Letter to Johannes Niemann', In Flanders Fields Museum (IFF), Ypres; Johannes Niemann 'Christmas Day Passed Quietly' BBC TV, November 1968, cited in Brown and Seaton, Christmas Truce. Frelinghien became the site of the first official memorial to the Christmas truces in 2008; serendipitously the village sports hall and football pitch have been built on the former No Man's Land where German troops famously rolled two barrels of beer across to the Royal Welch Fusiliers on Christmas Day 1914. Even though no football was reported as being played there then, commemorative games are sometimes held today.

${ }^{25}$ Klemm, 'letter'.

${ }^{26}$ Ibid.

${ }^{27}$ Niemann 'Christmas Day Passed Quietly', cited in Brown and Seaton, Christmas Truce, 56.

${ }^{28}$ Hugh Hyslop, 'Diary', Imperial War Museum, Archive 94/13/1.

${ }^{29}$ Graham Seton Hutchison, Pilgrimage (London: Rich \& Cowan, 1935), 226. Niemann cited by Brown and Seaton, Christmas Truce, 58.

${ }^{30}$ Brown and Seaton, Christmas Truce; John Aidan Liddle, 'Private Papers', Imperial War Museum, Document 11126; John Minnery, 'letter', The Barrhead News, 15 January 1915. Graham Seton, Footslogger: An Autobiography (London: Hutchinson, 1931), confusingly Graham Seton Hutchison also published under his middle name, Seton.

${ }^{31}$ Minnery, 'letter'. Liddell, 'Private Papers', also spoke with Schneider on Christmas Day identifying him as being from Glasgow and exchanged tobacco for some cigars.

${ }^{32}$ Hutchison, Pilgrimage, 226.

${ }^{33}$ War Diary, 2'Argyll \& Sutherland Highlanders.

${ }^{34}$ Frederick Chandler, RAMC. 'Diary and letters'. Imperial War Museum, Archive 60/77/1; Hutchinson, Pilgrimage; Liddle, 'Private Papers'; quote from Hyslop, 'Diary'.

${ }^{35}$ Klemm, 'letter'; Johannes Niemann, 'Das Spiel endete 3:2 für Fritz', in Johannes Niemann, Das 9. Königlich Sächsische Infanterie-Regiment Nr.133 im Weltkreig 1914-1918 (Hamburg-Grossflottbek: Selbstverl, 1969). This book is available at the Imperial War Museum, shelf mark 02(43).444 [133 Inf. Regt.1/3 and at IFF.The confusion may be because it was misty first thing in the morning and it was towards midday that the mist cleared sufficiently for the trenches to be visible to each other in the wider parts of No Man's Land.

${ }^{36}$ Klemm 'letter'.

${ }^{37}$ Chandler, 'Diary and letters'; Klemm, 'letter'; MacDonald, 1914-1918; Niemann, 'Das Spiel endete 3:2 für Fritz', 32.

${ }^{38}$ F.C. Collier, 'No 'ell in Houplines, Christmas Day, 1914', The Thin Red Line, (January 1965): 6-7.

${ }^{39}$ Hyslop, 'Diary'.

${ }^{40}$ Hutchison, Warrior, 63. Units on both sides tried to disguise their identity from the opposition. The 133/Saxons and 134/Saxons were members of the XIX ( $2^{\text {nd }}$ Royal Saxon) Army Corps and would have had insignia in common. However, the 2/Argylls definitely faced the 133/Saxons; the 134/Saxons were further north to the north-east of Ploegsteert Wood, see Adams and Petney, 'Germany 3 - Scotland 2', 21-41.

${ }^{41}$ Pehr Thermaenius, The Christmas Match (London: Uniform Press, 2014) places the game around the old road north of the agricultural suppliers; but that area was visible to the signallers of the abutting regiment who were based in Hobbs Farm. Although they fraternised there is no mention of football 
being played in their sight, Sergeant Bernard Brookes, A Signaller's War: Notes Compiled from My Diary 1914-1918 (Privately Published: Una Barrie, 2012).

${ }^{42}$ War Diary, $2^{\prime}$ Argyll \& Sutherland Highlanders.

${ }^{43}$ Ibid.

${ }^{44}$ John Terraine, General Jack's Diary: War on the Western Front (London: Cassell, 2000), 94.

${ }^{45}$ Seton, Footslogger, 138. Interestingly he records playing football for the Company on December 27; 'awfully sloppy ground, but good game', 138.

${ }^{46}$ Soldiers regularly wrote letters home about their experiences and, in the earlier years of the war, it was common practice for the families to pass the letters on to local newspapers for the community to share. The French government censored all accounts of the truces but both the British and German authorities permitted the press to mention the subject. Photographs of some of the truces appeared in papers such as The Daily Mirror, The Sphere and the ILN.

${ }^{47}$ Terraine, General Jack's Diary, 94.

${ }^{48}$ Adams and Petney, 'Germany 3 - Scotland 2'.

${ }^{49}$ During a research trip to sites of the truces in spring 2014, the author found the grave of Rifleman Robert Barnett of The Rifle Brigade. Robert was 15 when killed on 19 December 1914 despite the minimum enlistment age being 18. Regimental records indicate he joined up immediately at the start of the war, lying about his age and using his father's name, Raphael Glitzenstein, rather than his own; it is likely he joined the battalion as a battle casualty replacement. According to Gillott 'British Line Infantry Reserves' there is strong evidence that some volunteers were being sent to the front as reinforcements by mid-November 1914.

${ }^{50}$ Collier, 'No 'ell in Houplines'.

${ }^{51}$ Eksteins, Rites of Spring, 116.

52 Brown and Seaton Christmas Truce, 134.

${ }^{53}$ M. Jürgs, Der Kleine Frieden im Grossen Krieg (München: C. Bertelsmann, 2003).

${ }^{54}$ War Diary, ' $16^{\text {th }}$ Brigade, 1 Battalion Buffs (East Kent Regiment) 1 August 1914 -31 December 1914', National Archives, WO 95/1608/1; Iain Adams, 'A Game for Christmas? Football on the Western Front, December 1914', Public lecture, 11 December 2014, The National Archives, London. http://www.slideshare.net/The-National-Archives/tna-websitepowerpointgameforchristmas.

${ }_{55}^{5}$ Niemann, Das 9. Königlich Sächsische Infanterie-Regiment Nr.133; the official war diary of the 133 is missing from the Sächsisches Staatsarchiv in Dresden.

56 There is a significant library on football and the British army in The Great War; for example Iain Adams, 'Football: A Counterpoint to the Procession of Pain on the Western Front, 1914-1918?', Soccer \& Society 16.2-3 (2015): 217-231; Iain Adams and John Hughson, 'The First Ever Anti-Football Painting? A Consideration of the Soccer Match in John Singer Sargent's Gassed', Soccer \& Society (2013): 14.4 (2013): 502-514; James Dunbar Campbell, 'The Army Isn't All Work: Physical Culture in the Evolution of the British Army, 1860-1920' (PhD diss., University of Maine, 2003); Fuller, Troop Morale and Popular Culture; Brandon Luedtke 'Playing Fields and Battlefields: The Football Pitch, England and the First World War', Britain and the World, 5.1 (2012): 96-115;Tony Mason and Eliza Reidi, Sport and The Military: The British Armed Forces 1880-1960 (Cambridge: Cambridge University Press, 2010); James Roberts, “The Best Football Team, The Best Platoon”: The Role of Football in the Proletarianization of the British Expeditionary Force, 1914-1918', Sport in History, 26.1 (2006): 24-46; Vamplew, 'Exploding the Myths of Sport'; Colin Veitch, "Play Up! Play Up! And Win the War!": Football, the Nation and the First World War 1914-15', Journal of Contemporary History, 20 (1985): 363-378; Ross J. Wilson, 'It Still Goes On: Football and the Heritage of The Great War in Britain', Journal of Heritage Tourism, 9.3 (2014): 197-211.

${ }^{57}$ Edward Hardy, The British Soldier, His courage and Humour (London: T. Fisher Unwin, 1915), 185; Hutchison, Pilgrimage, 213; Terraine, General Jack's Diary, 91. For a more detailed analysis of the development of football in the BEF 1914-1918 see Adams, 'Football: A Counterpoint to the Procession of Pain'.

58 Thermaenius The Christmas Match.

${ }^{59}$ Thermaenius The Christmas Match; Stewart quoted by Brown and Seaton, Christmas Truce, 64; Generalleutnant Alfred D von Kotsch, Aus der Geschichte des früheren Kgl. Sächs. 9. InfanterieRegiments NR. 133 1881-1918 (Dresden: Wilhelm Limpert Verlag, 1924)

${ }^{60}$ A letter from a Highland regimental officer, The Glasgow News, 2 January 1915. Hutchison was a prolific author and letter writer, he was probably the author. A letter from a Sergeant, The Glasgow News, 2 January 1915.

${ }^{61}$ Parkhouse, G. 'The Miracle of No Man's Land: Who really Won the Christmas Day Football International', The Sunday Express, 22 December 1974, 8. 
${ }^{62}$ Richard Holmes, Introduction to My Bit: A Lancashire Fusilier at War 1914-1918, by George

Ashurst (Marlborough: Crowood, 2007), 8-9.

${ }^{63}$ A 'Black Maria' was a heavy German shell that exploded with a lot of black smoke.

${ }^{64}$ Frederick Coleman, From Mons to Ypres with French: A Personal Narrative (Toronto: William Briggs, nd), 296-297.

${ }^{65}$ Isle of Ely and Wisbech Advertiser, 3 February 1915 cited by A.J. Peacock, '1914: A

Christmas/Miscellany’, Gunfire: A Journal of First World War History 18 (nd): 32-39, 35.

${ }^{66}$ Adams, 'A Game for Christmas?' War Diary, '4 Battalion Seaforth Highlanders, 1 August 1914 - 30

November 1915’, National Archives, WO 95/3941/2.

${ }^{67}$ Klemm, 'letter'.

${ }^{68}$ Brown and Seaton, Christmas Truce, 137.

${ }^{69}$ Imperial War Museum photographic archive.

${ }^{70}$ Alan Weeks, A Bloody Picnic: Tommy's Humour, 1914-1918 (Stroud: the History Press, 2010);

${ }^{71}$ Niemann, 'Das Spiel endete 3:2 für Fritz', 32. An indistinct and somewhat blurry photograph taken by a 133 officer through his binoculars shows the Argylls and Saxons trucing in Nieman, Das 9. Königlich Sächsische Infanterie-Regiment Nr.133.

${ }^{72}$ Andrew Davidson, Fred's War: A Doctor in the Trenches (Edinburgh: Short Books, 2013), 208.

${ }^{73}$ Iain Adams, 'Over the Top: “A Foul; a Blurry Foul!"', The International Journal of the History of Sport 29, no. 6 (2012): 813-831.

${ }^{74}$ Cited by Alan Cleaver and Lesley Park, Not a Shot was Fired: Letters from the Christmas Truce 1914 (Raleigh, NC: Lulu, 2008), 60.

${ }^{75}$ Peter Daybell, With a Smile and a Wave: The Life of Captain Aidan Liddell, VC MC (Barnsley: Pen and Sword Aviation, 2005).

${ }^{76}$ Hutchison, Pilgrimage, 225, cited by Eksteins, Rites of Spring, 112.

${ }^{77}$ Niemann, 'Christmas Day Passed Quietly', cited in Brown and Seaton, Christmas Truce, 56.

${ }^{78}$ Brown and Seaton, Christmas Truce, 138.

${ }^{79}$ Brown and Seaton, Christmas Truce; Malcolm Brown, 'The Christmas Truce 1914: The British Story', in Marc Ferro, Malcolm Brown, Rémy Cazals and Olaf Mueller, eds, Meetings in No Man's Land: Christmas 1914 and fraternization in the Great War (London: Constable \& Robinson, 2007), 13-77; Stanley Weintraub, Silent Night.

${ }^{80}$ J.C. Latter, The History of the Lancashire Fusiliers 1914-1918, Volume 2 (Aldershot: Gale and Polden, 1949), 36; George Ashurst, My Bit: A Lancashire Fusilier at War (Marlborough: The Crowood Press, 1988), 41.

${ }^{81}$ C.B. Brockbank, 'Diary of a Lucky Man in the War 1914-1916' (Diary, Cheshire Military Museum, Chester).

${ }^{82}$ There are two other accounts of football from the 6/Cheshires which do not match Brockbank's story, but careful examination of the unit's war diary shows that each company was attached to different battalions over Christmas to get trench experience. Brockbank's 'C' Coy was with the 1/Norfolk's.

${ }^{83}$ Theresa Blom Crocker, 'A Remarkable Instance: The Christmas Truce and its role in the contemporaneous narrative of the First World War' (MA thesis, University of Kentucky, Lexington, Kentucky, 2012).

${ }^{84}$ Lieutenant Drummond of the Royal Field Artillery, cited by Brown and Seaton, Christmas Truce, 151.

${ }^{85}$ Henry Williamson, A Fox Under my Cloak (Macdonald, 1955), 11; Brown and Seaton, Christmas Truce, 102, 135.

${ }^{86}$ The British Council is the UK government's international organisation for cultural relations and educational opportunities.

${ }^{87}$ The UN Secretary General Ban Ki-moon participated, see "Commemorating the centenary of World War I 'Christmas Truce', NY http://www.rexfeatures.com/livefeed/2014/12/06/ [accessed 17 May 2015]; "New Ypres pitch 'a living statue' for Christmas Truce” http://www.premierleague.com/engb/news/news/2014-2015/nov/151114-premier-league-3g-pitch-in-ypres-opened-to-commemoratechristmas-truce.html [accessed 19 May 2015];

http://www.premierleague.com/en-gb/news/news/2013-14/dec/clubs-announced-for-2013-christmastruce-finals-in-ypres/ [accessed 23 December 2013]; http://www.premierleague.com/en-gb/news/201314/dec/truce-tournament [accessed 27 May, 2015];

http://www.britishcouncil.org/organisation/press/deadline-approaching-football-truce-schoolscompetition [accessed 12 October 2014].

${ }^{88} \mathrm{http}: / / \mathrm{ww} w . c e n t e n a r y n e w s . c o m / a r t i c l e ? i d=3088$ [accessed 22 June 2015]. 
${ }^{89}$ Steph Cockroft 'From the trenches to the beach: The poignant moment that two warring countries united over an impromptu football match is recreated in Teeside to commemorate the Great War', Daily Mail, 2 June 2014. Many commemorative games were organised in 2014, some like the one in Teeside used the football scene from Sebastian Faulks' novel Birdsong as a model and others the satirical film Oh What a Lovely War.

${ }^{90}$ Adams and Petney, 'Germany 3 - Scotland 2'; Jay Winter, 'The Generation of Memory: Reflections on the "Memory Boom" in Contemporary Historical Studies', Canadian Military History 10.3 (2001): 57-66; Vamplew, 'Exploding the Myths of Sport'. 